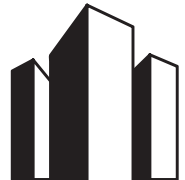

УДК 35.08

doi: $10.15421 / 15201727$

\title{
Впровадження асесмент-центрів як чинник ефективного розвитку служб управління персоналом державних органів
}

О. А. Носик

Харківський регіональний інститут держсавного управління Національної академії державного управління при Президентові України, Харків, Украӥна

У статті розглянуто умови створення та визначено аспекти функціонування асесмент-центрів як чинника ефективного розвитку служб управління персоналом державних органів у процесі реформування державного управління. Ці нові структурні підрозділи мають зосередити на собі ключові функції щодо реалізації державної політики з питань управління персоналом у державних органах. Асесмент-центри орієнтовані на оцінювання та діагностику реальних якостей працівників та кандидатів на посади державних службовців, їх психологічних і професійних особливостей. Ефективна реалізація методик оцінювання та діагностики працівників залежить від рівня підготовки фахівців асесмент-центрів, які повинні бути представлені своєрідною тріадою: безпосередньо працівниками служби управління персоналом, керівниками структурних підрозділів державного органу та залученими зовнішніми експертами високої та вищої кваліфікації. Визначено, що для створення і функціонування асесмент-центрів повинні бути створені нормативно-правові, кадрові та методологічні умови. Доведено, що створення і функціонування асесмент-центрів у структурі служб управління персоналом дозволять комплексно та різнобічно дослідити компетентності працівників і кандидатів на посади, визначити напрями подальшого розвитку їх професійної кваліфікації, а також стануть значним поштовхом ефективного розвитку служб управління персоналом державних органів.

Ключові слова: асесмент-інструментарій; добір компетентних кадрів; експерти високої та вищої кваліфікації; методики оцінювання та діагностики; компетенції; компетентності; людські ресурси; модернізація кадрових підрозділів; розвиток професійної компетентності

\section{Introduction of assessment centers as factor of effective development of personnel management services of state bodies}

\author{
O. A. Nosyk \\ Kharkiv Regional Institute of Public Administration of the National Academy for Public Administration \\ under the President of Ukraine, Kharkiv, Ukraine
}

Problem statement. One of the key aspects of modernizing approaches to managing human resources in civil service is formation of personnel management services at state bodies as the next stage of their development. The new structural units in question should focus on the major functions related to implementation of the state policy of managing personnel in public authorities. Analysis of modern research works devoted to the subject of framing the personnel management service of a state body gives evidence of insufficient methodological development of the problem, calling for attention to the theory and practice of personnel management in public administration.

Recent research and publication analysis. The problems of implementing state staffing policy, personnel management, and personnel service activities have been explored by N. Artemenko, S. Haiduchenko, S. Hazarian, Yu. Kalnysh, B. Kolesnikov V. Malynovsyi,, V. Oluiko, T. Pakhomova, O. Parkhomenko-Kutsevil, L. Pashko, A. Rachynskyi, V. Ryzhykh, S. Seriohin, I. Surai, V. Yatsuba and other researchers.

The paper objective is a study of conditions for introducing assessment centers as a factor of an effective development of personnel management services of public authorities.

The paper main body. In pursuance of the Law of Ukraine «On Civil Service», public authorities established their personnel management services. The services perform the functions of documenting civil servants' career progression, and are responsible for implementation of the state policy of personnel management in public bodies which, generally

Цитування даної статті: Носик О. А. Впровадження асесмент-центрів як чинник ефективного розвитку служб управління персоналом державних органів / О. А. Носик // Аспекти публічного управління. - 2017. T. 5. - № 8-9. - C. 47-55. doi: 10.15421/15201727

Citation of this article: Nosyk, O. A. (2017). Vprovadzhennya asesment-tsentriv yak chynnyk efektyvnoho rozvytku sluzhb upravlinnya personalom derzhavnykh orhaniv [Introduction of assessment centers as factor of effective development of personnel management services of state bodies]. Public administration aspects, 5(8-9), 47-55. doi: 10.15421/15201727 (in Ukrainian).

Received: 13.08 .2017

Accepted: 15.09.2017 
speaking, is the most important aspect of human resource management in a public institution.

Exercise of the functions and tasks imposed on the newly established services presupposes their continuous upgrading with the aim of a cardinal renovation of the substance of activity and enhancement of the role of managing public authority's staff. It is only possible if these issues are paid careful attention to at the very start, because some applicants start their career by entering civil service through a competition procedure, while others are recruited by evaluation of their service results through a range of tools of an assessment-center.

Based on the appropriate normative and legal framework, methodological recommendations should be elaborated for personnel management services of state bodies as regards organization of their civil servants' self-education; the relevant IT-aided study modules are to be developed; and the methods for raising the efficiency of evaluation and diagnostics of civil servants' professional competency are to be worked out and implemented.

In modern management, there are a large number of methods for personnel evaluation and diagnostics; however the most effective one at the current stage of public administration reform is creation of an assessment center within the structure of personnel management service - a center for a comprehensive assessment and diagnostics of staff. Apart from traditional questionnaires, interviews and situational tasks, an assessment center can apply mutually complementary evaluation and diagnostics methods which makes it possible to carry out a comprehensive research of competencies of staff and applicants for positions, their service and personal qualities, skills, and knowledge. Moreover, it is necessary to take into account the present underdeveloped state of the regulatory, staffing, and methodological support for introduction of assessment centers within the structure of personnel management services. Introduction of an assessment center does not require extra jobs for execution of this work; yet, essential supplements to the approved regulation are needed in terms of fulfillment of assessment functions by the service employees.

Conclusions. Introduction of an assessment center within the structure of personnel management services is a scientific and practical area of great current interest, which would provide an opportunity to investigate in a comprehensive and diverse manner the competencies of staff and applicants for positions, to identify the areas for further upgrading of their professional competence, and to provide a strong impetus for effective development of the personnel management services of public authorities. The conditions for establishment and functioning of an assessment center include: creation of a normative and legal support for the entire process, training of assessment staff, and selection of effective methods for civil servants' evaluation and diagnostics.

Keywords: assessment range of tools; selection of competent cadres; experts of high and highest qualification; methods of assessment and diagnostics; competences; competency; human resources; modernization of staffing units; development of professional competency

\title{
Внедрение ассессмент-центров как фактор эффективного развития служб управления персоналом государственных органов
}

\author{
О. А. Носик \\ Харьковский региональный институт государственного управления \\ Национальной академии государственного управления при Президенте Украины, \\ Харьков, Украина
}

В статье рассмотрены условия создания и определены аспекты функционирования ассессмент-центров как фактора эффективного развития служб управления персоналом государственных органов в процессе реформирования государственного управления. Эти новые структурные подразделения должны сосредоточить на себе ключевые функции по реализации государственной политики по вопросам управления персоналом в государственных органах. Ассессмент-центры ориентированы на оценку и диагностику реальных качеств работников и кандидатов на должности государственных служащих, их психологических и профессиональных особенностей. Эффективная реализация методик оценки и диагностики работников зависит от уровня подготовки специалистов ассессмент-центров, которые должны быть представлены своеобразной триадой: непосредственно работниками службы управления персоналом, руководителями структурных подразделений государственного органа и привлеченными внешними экспертами высокой и высшей квалификации. Определено, что для создания и функционирования ассессмент-центров должны быть созданы нормативно-правовые, кадровые и методологические условия. Доказано, что создание и функционирование ассессмент-центров в структуре служб управления персоналом позволят комплексно и всесторонне исследовать компетентности работников и кандидатов на должности, определить направления дальнейшего развития их профессиональной квалификации, а также станут значительным толчком эффективного развития служб управления персоналом государственных органов.

Ключевые слова: ассессмент-инструментарий; подбор компетентных кадров; эксперты высокой и высшей квалификации; методики оценки и диагностики; компетенции; компетентности; человеческие ресурсы; модернизация кадровых подразделений; развитие профессиональной компетентности 
Постановка проблеми. Одним із ключових аспектів модернізації підходу до управління людськими ресурсами на державній службі $з$ метою приведення іiі у відповідність до принципів та стандартів Свропейського Союзу $\epsilon$ формування служб управління персоналом у державних органах як наступний етап розвитку кадрових служб [12].

Ці нові структурні підрозділи мають зосередити на собі ключові функції щодо реалізації державної політики 3 питань управління персоналом у державних органах, а також добір персоналу, планування, організацію заходів 3 питань підвищення рівня професійної компетентності державних службовців, оцінювання їх службової діяльності, документальне оформлення вступу на державну службу, ii проходження та припинення, а також інші функції, передбачені законодавством. Держава розраховує, що кадровий склад державної служби значно посилиться саме завдяки діяльності служб управління персоналом за міжнародними стандартами.

До недавнього часу саме поняття «служба управління персоналом державного органу» в управлінській практиці було відсутнє. Це відображає слабку методологічну розробленість даної проблеми і доводить, що це питання ще не було об'єктом уваги наукової галузі «Державне управління». Аналіз сучасних досліджень, присвячених проблемі розвитку служби управління персоналом державного органу, свідчить про значну увагу до теорії та практики управління персоналом в цілому та в державному управлінні зокрема.

Аналіз досліджень і публікацій. Серед вітчизняних учених, які опікувалися проблемами реалізації державної кадрової політики, питаннями, що стосуються управління персоналом, діяльності кадрових служб, трудових відносин та державної служби, можна назвати В. Побережну [14], К. Ващенка, Ю. Ковбасюка, Ю. Сурміна, О. Оболенського, С. Серьогіна та ін. $[7 ; 8 ; 21]$. Б. Колесніков науково обгрунтував необхідність створення регіональної аутсорсингової кадрової служби задля забезпечення переходу від діловодної моделі кадрових служб до функціонально багатовимірної діяльності з управління персоналом державної служби та служби в органах місцевого самоврядування на основі аутсорсингу [11]. А. Рачинський звертав увагу науковців на теоретико-методологічні та практико-прикладні засади стратегічного управління персоналом у діяльності органів державної влади [20]. Теоретичні і практичні аспекти оцінювання людських ресурсів у сфері державного управління розглянуті Л. Пашко, яка науково-теоретично обгрунтувала цей процес крізь призму ділової результативності, професійної продуктивності та персональної ефективності діяльності [13]. С. Гайдученко теоретично обгрунтувала формування інноваційної технології оцінювання в управлінні персоналом державної служби, розробила алгоритм іiі реалізації і практичні рекомендації щодо іiї застосування [3]. У наукових публікаціях В. Волик звертав увагу на організаційний підхід до управління розвитком компетентностей державних службовців [2], а В. Дементов обгрунтував, що в умовах реформування державного управління в Україні управління людськими ресурсами державної служби має грунтуватись на мотивації до саморозвитку [6]. Такий актуальний напрям досліджень, як професіоналізація державної служби та розробка організаційно-функціональної структури служби управління персоналом державного органу отримали розвиток у роботах С. Газарян $[4 ; 5]$ та ін.

На теперішній час, коли кадрові підрозділи державних органів вже трансформовані в служби управління персоналом, актуальним $\epsilon$ напрям наукових досліджень щодо розвитку цих служб, вироблення практичних рекомендацій і підходів до реалізації функцій управління персоналом, переходу до нових сучасних форм роботи 3 кадрами, їх оцінювання та діагностики.

Аналіз світового досвіду роботи 3 персоналом, наприклад у США, країнах Західної Свропи, свідчить про ефективне використання асесмент-центрів як одного 3 методів комплексного оцінювання персоналу, заснованого на використанні взаємодоповнюючих методик, орієнтованого на оцінку реальних якостей співробітників, їх психологічних i професійних особливостей, а також виявлення потенційних можливостей фахівців. Вважається, що на сьогоднішній день метод асесментцентру $є$ одним 3 найбільш точних методів оцінки компетенцій співробітників [22], тому метою дослідження $\epsilon$ розгляд умов впровадження асесмент-центрів як чинника ефективного розвитку служб управління персоналом державних органів. Для досягнення мети поставлені завдання щодо визначення специфіки асесмент-центрів, розгляду умов функціонування та окреслення напрямків їх діяльності в 
структурі служб управління персоналом державних органів.

Виклад основного матеріалу. На виконання норм Закону України «Про державну службу» [16] в державних органах створені служби управління персоналом, які діють відповідно до затверджених положень [17]. На відміну від звичайних кадрових підрозділів служби управління персоналом мають не тільки функції з документального оформлення проходження кар'єри державних службовців, вони є відповідальними за реалізацію державної політики 3 питань управління персоналом у державному органі, що $є$ найважливішим аспектом управління людськими ресурсами в конкретній установі в цілому.

Виконання покладених функцій i завдань новоствореними службами передбачає їх постійний розвиток з метою кардинального оновлення змісту діяльності та посилення ролі в управлінні персоналом державного органу. Ефективне здійснення такої місії служб управління персоналом має полягати в їх організаційному розвитку через заходи 3 проведення аналітичної роботи у галузі кадрового менеджменту. Ці служби мають здійснювати короткострокове та довгострокове прогнозування розвитку персоналу, вживати цілеспрямовані заходи щодо підвищення кваліфікації державних службовців відповідно до розроблених індивідуальних програм підвищення рівня професійної компетентності, які складаються за результатами оцінювання та діагностики службової діяльності працівників, а також з організації професійного неупередженого добору компетентних кадрів. Це можливо лише якщо на старті приділяти цим моментам спеціальну увагу (для когось старт - це вступ на держслужбу через процедуру конкурсу, а для когось - перше оцінювання результатів службової діяльності через інструментарій асесмент-центру).

Розробка варіантів планових дій здійснюється 3 обов'язковим урахуванням того, що на різні посади державної служби призначаються особи із різним досвідом та різними компетентностями. Саме ці аспекти мають бути визначальними у розробці різноманіття варіантів планових дій.

Аналіз основних стратегічних документів держави $[9 ; 18 ; 19]$ дозволяє стверджувати, що концептуальні положення щодо функціонування служб управління персоналом вже визначені, окреслені основні напрями та за- ходи, відповідно до яких повинні розвиватися ці підрозділи. За умови створення певної нормативно-правової бази мають бути розроблені методичні рекомендації для служб управління персоналом державних органів щодо організації самоосвіти державних службовців та відповідні навчальні модулі з використанням інтерактивних технологій, розроблені та впроваджені методики оцінювання й діагностики ефективності підвищення професійної компетентності державних службовців тощо.

Особливо важливою $є$ розробка нормативно-правової бази щодо діяльності служб управління персоналом державних органів саме в частині можливої появи в їх структурі асесмент-центрів, бо асесмент-інструментарій має велике значення для розкриття найважливіших для конкретної діяльності сторін особистості (мораль, здібності, нахили, досвід тощо).

У сучасному менеджменті існує велика кількість методик оцінювання та діагностики персоналу - описова методика оцінки, методика класифікації, методика моделювання ситуації, методика анкетування, методика алфавітно-числової шкали, методика «360 градусів» та ін., кожна 3 яких має свої особливості та умови застосування. Найбільш ефективним на теперішньому етапі реформування державного управління 3 наближенням його до європейських стандартів є створення в структурі служби управління персоналом асесмент-центру - центру 3 комплексного оцінювання та діагностики персоналу.

При цьому, крім традиційних анкет, інтерв'ю та ситуативних завдань, слід використовувати і спеціальні тести якостей особистості - психометрію. Маються на увазі i проективні методики (наприклад матриці Джона Равена, «Плями Роршаха»), і вимірювальні тести інтелекта Г. Айзенка тощо [1; 10]. Тобто, однією зі сторін діяльності асесмент-центру є своєрідний поліграф, який відображає та вимірює найбільш важливі для державної служби якості особистості. Цей підхід давно став природним шаблоном для аналогічних асесмент-центрів розвинутих країн. Нам цим підходом треба ще оволодіти.

Асесмент-центр заснований на використанні взаємодоповнюючих методик оцінювання та діагностики. Саме взаємодоповнюваність методик задає комплексний характер системам оцінювання асесмент-центру, що дає змогу оцінити як ділові, так і особисті якості, 
навички, знання працівників (саме ці прояви $\epsilon$ предикатами поняття компетентність). Для державних службовців, які призначаються на посаду тільки за результатами конкурсу, етап проходження асесмент-центру $є$ принциповою складовою участі у конкурсі. При цьому треба враховувати недостатню на цей час нормативну й інструментальну забезпеченість асесмент-центрів у структурі служб управління персоналом.

Слід відмітити необхідність наявності висококваліфікованих співробітників цих служб, які повинні володіти загальносоціологічною, психометричною та кваліметричною часткою відповідного інструментарію. Це свідчить про особливі критерії підбору кадрів для цього підрозділу. Враховуючи недостатність або відсутність спеціальної освіти для цієї роботи, потрібні деякі модернізації щодо спеціалізацій у відповідних вузах та програм у центрах підготовки та перепідготовки кадрів: наприклад, 3 організації інтерв'ю, зі створення анкет та методики ї проведення, аналізу отриманої у результаті цього інформації тощо.

Отримати ці спеціальні знання та вміння (компетенції) безперечно можна i в режимі самоосвіти. Але значно ефективніше ця діяльність буде відбуватися, якщо базою персоналу служб стануть класично освічені спеціалісти. 3 урахуванням того, що трансформація кадрових служб у служби управління персоналом $\epsilon$ загальнодержавною практикою в органах, де працюють державні службовці, доцільним було б створення факультетів перепідготовки кадрових працівників при найбільш знакових системних вишах України. У цьому випадку підготовку фахівців асесмент-центрів будуть вести спеціалісти-психологи, спеціалісти-педагоги, спеціалісти-комп'ютерники тощо, тобто експерти у своїй конкретній справі.

Пояснимо закладений нами сенс у поняття експертів. Кваліметричні методики оцінювання дають кількісні (дуже зручні для порівняння) результати, які вкладаються у формули, схеми, шкали та співвідношення. Психометричні методики мають опрацьовані десятиріччями стандарти висновків. Але деякі прояви особистих та ділових якостей стандартизованому вимірюванню не підлягають. У таких випадках оцінювання має проводитися у формі експерт-оцінок - якісних описів. Експертами виступають ті, кого висококваліфіковані фахівці вважають висококваліфікованими фахівцями (це найбільш стисле, але й най- більш адекватне, 3 нашої точки зору, визначення поняття «експерт»). Безумовно, крім найвищої кваліфікації, експерти повинні володіти моральною репутацією, що цілковито необхідно для членів конкурсних комісій установ. Ключові риси експертів - їх кваліфікація, репутація, неупередженість. Таким чином, асесмент-центри сприяють появі інституту експертів на рівні кожного державного органу.

Асесмент-центри орієнтовані на оцінювання та діагностику реальних якостей учасників, їх психологічних і професійних особливостей, відповідності вимогам посадових інструкцій, а також на виявлення потенційних можливостей фахівців. Методики оцінювання та діагностики компетенцій працівників та кандидатів на посади, спостереження за їх реальною поведінкою, яку вони демонструють в ділових іграх та тренінгах, суттєво підвищують вірогідність якісного висновку щодо наявного потенціалу кандидата на посаду або $\epsilon$ підставою для складання індивідуальної програми підвищення рівня професійної компетентності та подальшого розвитку працівника.

У варіантах планових дій, які розробляються асесмент-центрами для конкурсів та щорічного оцінювання, крім вищезазначеного, мають бути ситуативні ігри, де б претенденти на посади або працівники, які проходять оцінювання, грали активну роль, мали можливість креативно діяти, шукати та знаходити рішення в проблемних ситуаціях.

До структури діяльності асесмент-центру повинні входити традиційні, звичні методики оцінювання та діагностики:

- інтерв'ю, у ході якого йде збір даних про знання і досвід працівника чи кандидата на посаду;

- психологічні, професійні та загальні тести;

- коротка презентація працівника чи кандидата на посаду перед іншими працівниками чи кандидатами на посади;

- ділова гра за участю працівника чи кандидата на посаду;

- біографічне анкетування працівника чи кандидата на посаду;

- опис професійних досягнень працівника чи кандидата на посаду;

- індивідуальний аналіз конкретних ситуацій, коли працівнику чи кандидату на посаду пропонується вибрати певну стратегію і тактику дій в запропонованій ситуації;

- спостереження, за результатами якого 
складаються експертні висновки та рекомендації для кожного працівника та робиться висновок про відповідність претендента вакантній посаді.

До вимог діяльності асесмент-центрів можна віднести об’єктивність та незалежність від ситуації та особистості працівника чи кандидата на посаду, точність параметрів оцінювання (краще всього це - кваліметричні та психометричні показники), якісний опис експертами визначених проявів особистості, прогностичність (можливість передбачити хоча б основні прояви поведінки людини в професійних ситуаціях), прагматична корисність (для керівників - у можливості використовувати результати оцінки для прийняття кадрових рішень, для працівника чи кандидата на посаду - у можливості використовувати результати оцінки для саморозвитку).

Використання різних методик оцінювання та діагностики персоналу дозволять побачити прояви компетенцій та компетентностей працівника чи кандидата на посаду у будь-якому питанні та по-новому вибудувати цілу низку кадрових процесів, таких як оцінка професіоналізму державних службовців, кар'єрне зростання, оцінка інноваційного і лідерського потенціалу, проведення масштабних змін тощо. Ефективна реалізація методик оцінювання та діагностики працівника чи кандидата на посаду залежить від рівня підготовки для цієї діяльності персоналу асесмент-центру, який повинен вміти проаналізувати наявні людські ресурси, оцінити, наскільки ефективно вони використовуються і які передбачаються перспективи їх розвитку. Крім того, персональний склад конкурсних комісій структурно повинен бути своєрідною тріадою, а саме:

- працівники самої служби управління персоналом, які перевіряють загальні компетентності працівника чи кандидата на посаду, а також проводять діагностичну діяльність відповідно до затвердженого регламенту;

- керівники / заступники керівників структурних підрозділів державного органу, куди претендують кандидати на посади або підлеглі працівники яких проходять щорічне оцінювання, предметом діяльності яких буде перевірка особливих компетентностей кандидата на посаду чи працівника (при цьому критері$\epsilon м$ залучення цих співробітників $є$ співвідношення їх специфіки діяльності з компетентністю працівника, яка перевіряється);
- залучені зовнішні експерти високої та вищої кваліфікації - працівники інших установ, які перевіряють найважливіші індивідуальні потенціали працівника чи кандидата на посаду на відповідність компетентностям, що необхідні для претендентів на ключові посади в установі.

Кожен державний службовець через процедуру оцінювання та діагностики отримує потужний імпульс до розвитку. По-перше, йому надають повну інформацію щодо рівня його професіоналізму в конкретній галузі. Подруге, кожна людина отримує можливість випробувати варіанти поведінки в проблемних ситуаціях, оцінити свій потенціал та опанувати індивідуальну програму підвищення рівня професійної компетентності [23].

Оволодіння та використання методик асесмент-центру потребує специфічної підготовки, бо вони є досить трудомісткими та вимагають багато часу як для підготовчих робіт, так і для самого оцінювання та діагностики. Ці питання вирішуються завдяки успішному підбору працівників служб управління персоналом, фахівців, які залучаються 3 даної установи, та зовнішніх експертів відповідного профілю [15].

Треба зазначити, що впровадження асесмент-центру не передбачає додаткових штатів для здійснення зазначеної роботи, але передбачає суттєві доповнення до затвердженого положення [17] в частині здійснення працівниками служби асесмент-функцій.

Висновки. Таким чином, створення асесмент-центру в структурі служб управління персоналом $\epsilon$ актуальним напрямом науково-практичного дослідження, яке дасть можливість комплексно та різнобічно дослідити компетентність працівників i кандидатів на посади, визначити напрями подальшого розвитку їх професійної кваліфікації, а також стане значним поштовхом ефективного розвитку служб управління персоналом державних органів. На сьогоднішній день умовами для створення i функціонування асесмент-центру як чинника ефективного розвитку служб управління персоналом $є$ : створення нормативно-правового супроводу всього цього процесу (нормативно-правова умова), підготовка асесмент-персоналу (кадрова умова), підбір ефективних методик оцінювання та діагностики державних службовців (методологічна умова). 


\section{БІБЛІОГРАФІЧНІ ПОСИЛАННЯ:}

1. Бурлачук Л. Ф. Введение в проективную психологию / Бурлачук Л. Ф.. — Киев: Ника-Центр, 1997. — 128 с. 2. Волик В. С. Управління розвитком компетентностей державних службовців в Україні. : автореф. дис. ... канд. наук з держ. упр. : спец. 25.00.03 - держ. служба / В'ячеслав Сергійович Волик. - Дніпропетровськ, 2015. -23 c.

3. Гайдученко С. О. Формування інноваційної технології оцінювання в управлінні персоналом. державної служби. : автореф. дис. ... канд. наук з держ. упр. : спец. 25.00.03 - держ служба / Світлана Олександрівна Гайдученко. - Дніпропетровськ, 2010. - 20 с.

4. Газарян С. В. Організаційно-функціональна структура служби управління персоналом державного органу у відповідності до принципу меритократії / С. В. Газарян, О. А. Носик // Державне будівництво : [фах. електрон. наук вид.]. - Х. : Вид-во ХарРІ НАДУ «Магістр». - 2017. - № 2. - Режим доступу : http://www.kbuapa. kharkov.ua/e-book/db/2017-2/index.html

5. Газарян С. В. Професіоналізація служби в органах місцевого самоврядування: зміст, форми та методи : автореф. дис. ... д-ра наук з держ. упр. : спец. 25.00.03 - держ. служба / Світлана Вікторівна Газарян. - К., 2011, $36 \mathrm{c}$.

6. Дементов В. О. Розвиток державної служби в умовах реформування державного управління в Україні : автореф. дис. ... канд. наук з держ. упр. : спец. 25.00.03 - держ. служба / Володимир Олександрович Дементов. - Дніпропетровськ, 2014. - 23 с.

7. Державна кадрова політика в Україні : стан, проблеми та перспективи розвитку : наук. доп. / авт. кол. : Ю. В. Ковбасюк, К. О. Ващенко, Ю. П. Сурмін та ін. ; за заг. ред. д-ра наук з держ. упр., проф. Ю . В . Ковбасюка, д-ра політ. наук, проф. К. О. Ващенка, д-ра соц. наук, проф. Ю. П. Сурміна (кер. проекту). - К. : НАДУ, 2012. $-72 \mathrm{c}$

8. Державна служба : підручник у 2 т. / [редкол. : Ю. В. Ковбасюк (голова), О. Ю. Оболенський (заст. голови), С. М. Серьогін (заст. голови) та ін.] ; Нац. акад. держ. упр. при Президентові України. - К. ; Одеса : НАДУ, 2013. - T. 2. -348 c

9. Деякі питання реформування державного управління України : Розпорядження Кабінету Міністрів України від 24 червня 2016 р. № 474-р // Урядовий кур`єр - 2016. - № 139

10. Кірсанов В. В. Психолого-педагогічна діагностика: Підручник. /Кірсанов Володимир Володимирович. - К. : «Альтерпрес», 2002

11. Колесніков Б. П. Реформування кадрових служб органів державної влади та місцевого самоврядування в Україні : автореф. дис. ... канд. наук з держ. упр. : спец. 25.00.03 - держ. служба / Борис Петрович Колесніков. - Дніпропетровськ, 2005. - 22 с.

12. Модернізація державного управління та європейська інтеграція України : наук. доп. / [Ю. В. Ковбасюк, К. О. Ващенко, Ю. П. Сурмін та ін.] ; за заг. ред. Ю. В. Ковбасюка. - К. : НАДУ, 2013. - 120 с.

13. Пашко Л. А. Людські ресурси у сфері державного управління: теор.-методол. засади оцінювання : автореф. дис. ... д-ра наук з держ. упр. : спец. 25.00.03 - держ. служба / Людмила Андріївна Пашко. - К., 2007. - 27 с. 14. Побережна В. А. Формування та реалізація державної кадрової політики у сфері державної служби України : автореф. дис. ... канд. наук з держ. упр.: спец. 25.00.03 - держ. служба / Віта Анатоліївна Побережна. - К., 2014. $-23 \mathrm{c}$.

15. Применение метода центра оценки на государственной службе как условие оптимизации оценки управленческих кадров / Ряховская Татьяна Викторовна. Политическое управление: научный информационнообразовательный электронный журнал (Political management: Scientific Information and Education Web Journal). [Сетевое электронное издание, ISSN 2221-7703]. 2013. № 03 (06). Оригинал статьи -URL: http://www.политуправление.pф/arhiv/2013/03/RyakhovskayaTV.htm, c. 81

16. Про державну службу : Закон України від 10 груд. 2015 р. № 889-VIII // Офіційний вісник України. - 2016. - № 3. - С. 28. - Ст. 149

17. Про затвердження типового положення про службу управління персоналом державного органу : Наказ Національного агентства України з питань державної служби від 03.03.2016 № 47, зареєстрований в Міністерстві юстиції України 23 березня 2016 р. за № 438/28568 / Режим електронного доступу : http://zakon3.rada.gov.ua/ laws/show/z0438-16

18. Про Стратегію сталого розвитку «Україна - 2020» : Указ Президента України від 12 січ. 2015 р. № 5/2015 // Офіційний вісник України. - 2015. - № 4. - С. 8. - Ст. 67

19. Про схвалення Стратегії реформування державної служби та служби в органах місцевого самоврядування в Україні на період до 2017 року та плану заходів щодо ііі реалізації : Розпорядження Кабінету Міністрів України від 18 березня 2015 р. № 227-р // Урядовий кур“єр. - 2015. - № 63

20. Рачинський А. П. Стратегічне управління персоналом органів державної влади: теор.-методол. засади. : автореф. дис. ... д-ра наук з держ. упр. : спец. 25.00.03 - держ. служба / Анатолій Петрович Рачинський. - К., 
2011. $-38 \mathrm{c}$.

21. Серьогін С.М. Мета, завдання та функції державної служби / С.М.Серьогін // Аспекти публічного управління. - 2013. - №1 (1). - С. 58-65.

22. Стратегічне управління людськими ресурсами : навчальний посібник / С. Г. Матвїшин. - Львів : ЛРІДУ НАДУ, 2011. — 200 с. — ISBN 978-966-8687-93-8

23. Хермелин И., Лайвенс Ф., Робертсон А.Т. Прогностическая валидность Центра оценки: метаанализ [Электронный ресурс] // Организационная психология. 2011. Т. 1. № 1. С. 39-49. URL: http://orgpsyjournal.hse. ru (дата обращения: 07.10.2017 г.)

\section{REFERENCES:}

1. Burlachuk, L. F. (1997). Vvedenie v proektivnuyu psihologiyu [Introduction to projective psychology]. Kiev, NikaTsentr (in Russian).

2. Volyk, V. S. (2015). Upravlinnya rozvytkom kompetentnostey derzhavnykh sluzhbovtsiv v Ukrayini [Management of development of competences of civil servants in Ukraine]. Dnipropetrovs'k (in Ukrainian).

3. Hayduchenko, S. O. (2010). Formuvannya innovatsiynoyi tekhnolohiyi otsinyuvannya v upravlinni personalom. derzhavnoyi sluzhby [Formation of innovative evaluation technology in human resources management. civil service]. Dnipropetrovs'k (in Ukrainian).

4. Hazaryan, S. V. (2017). Orhanizatsiyno-funktsional'na struktura sluzhby upravlinnya personalom derzhavnoho orhanu u vidpovidnosti do pryntsypu merytokratiyi [Organizational-functional structure of the personnel management service of the state body in accordance with the principle of meritocracy]. Derzhavne budivnytstvo: [fakh. elektron. nauk vyd.], 2. Kh.: Vyd-vo KharRI NADU «Mahistr». Access mode: http://www.kbuapa.kharkov.ua/e-book/db/20172/index.html (in Ukrainian).

5. Hazaryan, S. V. (2011). Profesionalizatsiya sluzhby v orhanakh mistsevoho samovryaduvannya: zmist, formy ta metody [Professionalization of service in local self-government bodies: content, forms and methods]. Kyiv (in Ukrainian).

6. Dementov, V. O. (2014). Rozvytok derzhavnoyi sluzhby $v$ umovakh reformuvannya derzhavnoho upravlinnya $v$ Ukrayini [Development of civil service in the context of reforming public administration in Ukraine]. Dnipropetrovs' $\mathrm{k}$ (in Ukrainian).

7. Kovbasyuk, Yu. V., \& Vashchenko, K. O., \& Surmin, Yu. P. (2012). Derzhavna kadrova polityka v Ukrayini : stan, problemy ta perspektyvy rozvytku : nauk. dop. [State staff policy in Ukraine: state, problems and prospects of development]. Kyiv, NADU (in Ukrainian).

8. Kovbasyuk, Yu. V., \& Obolens'kyy, O. Yu., \& Ser'ohin, S. M. (2013). Derzhavna sluzhba [Public Service]. Vol. 2. Kyiv; Odesa: NADU (in Ukrainian).

9. Deyaki pytannya reformuvannya derzhavnoho upravlinnya Ukrayiny: Rozporyadzhennya Kabinetu Ministriv Ukrayiny vid 24 chervnya 2016 r. № 474-r [Some Issues in the Reform of the Public Administration of Ukraine: Order of the Cabinet of Ministers of Ukraine of June 24, 2016 № 474-p]. (2016). Uryadovyy kur 'yer, 139 (in Ukrainian). 10. Kirsanov, V. V. (2002). Psykholoho-pedahohichna diahnostyka [Psychological-pedagogical diagnostics]. Kyiv, «Al'terpres» (in Ukrainian).

11. Kolesnikov, B. P. (2005). Reformuvannya kadrovykh sluzhb orhaniv derzhavnoyi vlady ta mistsevoho samovryaduvannya $v$ Ukrayini [Reform of personnel services of state authorities and local self-government in Ukraine]. Dnipropetrovs'k (in Ukrainian).

12. Kovbasyuk, Yu. V., \& Vashchenko, K. O., \& Surmin, Yu. P. (2013). Modernizatsiya derzhavnoho upravlinnya ta yevropeys 'ka intehratsiya Ukrayiny [Modernization of public administration and European integration of Ukraine]. Kyiv, NADU (in Ukrainian).

13. Pashko, L. A. (2007). Lyuds'ki resursy u sferi derzhavnoho upravlinnya: teor-metodol. zasady otsinyuvannya [Human resources in the field of public administration: theoretical and methodological. evaluation principles]. Kyiv (in Ukrainian).

14. Poberezhna, V. A. (2014). Formuvannya ta realizatsiya derzhavnovi kadrovovi polityky u sferi derzhavnovi sluzhby Ukrayiny [Formation and realization of the state personnel policy in the field of civil service of Ukraine]. Kyiv (in Ukrainian).

15. Ryahovskaya, T. V. (2013). Primenenie metoda tsentra otsenki na gosudarstvennoy sluzhbe kak uslovie optimizatsii otsenki upravlencheskih kadrov [Application of the assessment center method in the civil service as a condition for optimizing the evaluation of management personnel]. Politicheskoe upravlenie: nauchnyiy informatsionno-obrazovatelnyiy elektronnyiy zhurnal (Political management: Scientific Information and Education Web Journal), 03 (06). Access mode: http://www.politupravlenie.rf/arhiv/2013/03/RyakhovskayaTV.htm, s. 81 (in Russian).

16. Pro derzhavnu sluzhbu : Zakon Ukrayiny vid 10 hrud. 2015 r. № 889-VIII [On the Civil Service: The Law 
of Ukraine of December 10. 2015 p. № 889-VIII]. (2016). Ofitsiynyy visnyk Ukrayiny, 3, 28 (in Ukrainian). 17. Pro zatverdzhennya typovoho polozhennya pro sluzhbu upravlinnya personalom derzhavnoho orhanu : Nakaz Natsional'noho ahent·stva Ukrayiny z pytan' derzhavnoyi sluzhby vid 03.03.2016 № 47, zareyestrovanyy v Ministerstvi yustytsiyi Ukrayiny 23 bereznya 2016 r. za № 438/28568 [On Approval of the Standard Provision on the Personnel Management Service of a State Body: Order of the National Agency of Ukraine on Civil Service dated 03.03.2016 № 47, registered with the Ministry of Justice of Ukraine on March 23, 2016, under № 438/28568]. Access mode: http://zakon3.rada.gov.ua/laws/show/z0438-16 (in Ukrainian).

18. Pro Stratehiyu staloho rozvytku «Ukrayina - 2020» : Ukaz Prezydenta Ukrayiny vid 12 sich. 2015 r. № 5/2015 [On the Strategy of Sustainable Development "Ukraine 2020": Decree of the President of Ukraine dated January 12. 2015 number 5/2015]. (2015). Ofitsiynyy visnyk Ukrayiny, 4, 8 (in Ukrainian).

19. Pro skhvalennya Stratehiyi reformuvannya derzhavnoyi sluzhby ta sluzhby v orhanakh mistsevoho samovryaduvannya v Ukrayini na period do 2017 roku ta planu zakhodiv shchodo yiyi realizatsiyi : Rozporyadzhennya Kabinetu Ministriv Ukrayiny vid 18 bereznya 2015 r. № 227-r [On Approving the Strategy for Reforming the Civil Service and Service in Local Self-Government Bodies in Ukraine for the Period until 2017 and Action Plan for its Implementation: Order of the Cabinet of Ministers of Ukraine dated March 18, 2015, No. 227-p]. (2015). Uryadovyy kur 'yer, 63 (in Ukrainian).

20. Rachyns'kyy, A. P. (2011). Stratehichne upravlinnya personalom orhaniv derzhavnoyi vlady: teor.-metodol. zasady. [Strategic management of personnel of public authorities: theoretical and methodological. the ambushes]. Kyiv (in Ukrainian).

21. Ser'ohin, S. M. (2013). Meta, zavdannya ta funktsiyi derzhavnoyi sluzhby [Purpose, tasks and functions of the civil service]. Aspekty publichnoho upravlinnya, 1(1), 58-65 (in Ukrainian).

22. Stratehichne upravlinnya lyuds'kymy resursamy : navchal'nyy posibnyk [Strategic Human Resource Management]. (2011). L'viv, LRIDU NADU (in Ukrainian)

23. Hermelin, I., Layvens, F., Robertson, A. T. (2011). Prognosticheskaya validnost Tsentra otsenki: metaanaliz [Prognostic Validity of the Evaluation Center: meta-analysis]. Organizatsionnaya psihologiya, 1(1), 39-49. Access mode: http://orgpsyjournal.hse.ru (in Russian).

Носик Оксана Анатолї̈вна - аспірант кафедри державного управління

Харківський регіональний інститут державного управління Національної академії державного управління при Президентові Украӥни

Адреса: 61000, л. Харків, пр. Московський, 75

E-mail: kadri_GU@ukr.net

Nosyk Oksana A. - postgraduate. department of public administration

Kharkiv Regional Institute of Public Administration of the National Academy for Public Administration under the President of Ukraine

Address: 75, Moskovskyy Av., Kharkiv, 61000, Ukraine

E-mail:kadriGU@ukr.net

ORCID 0000-0002-9114-0118 